\title{
KEPUASAN WISATAWAN PADA DESTINASI AGRO WISATA DI BOGOR
}

\author{
Mellia Jeneetica \\ Sekolah Tinggi Pariwisata Bogor, mellia@stpbogor.ac.id
}

\begin{abstract}
ABSTRAK
Agro wisata merupakan destinasi wisata yang cukup menarik bagi keluarga. Selain mendapatkan kesenangan, wisatawan juga mendapatkan edukasi mengenai tanaman dan pertanian. Hanya saja perlu diketahui tingkat kepuasan pengunjung mengingat banyaknya pesaing dari destinasi wisata yang lain yang semakin berkembang dan inovatif. Penelitian ini menggambarkan kepuasan wisatawan ketika berkunjung ke salah satu Agro wisata ternama di Bogor, di mana terbatas pada kepuasan wisatawan saja tanpa melihat variable lain. Hal ini dilakukan untuk melihat kepuasan wisatawan ketika mengunjungi atau melakukan kegiatan di agro wisata. Penelitian ini menggunakan metode penelitian kuantitatif deskriptif. Hasil yang didapatkan bahwa sebagian besar responden menyatakan puas setelah mengunjungi atau melakukan kegiatan di agro wisata. Hal ini tentunya dapat menjadi masukan untuk penyedia jasa.
\end{abstract}

Kata kunci: Kepuasan Wisatawan, Agro Wisata, Traveller, Consumer Behavior, Tourism, Perjalanan Wisata.

\section{PENDAHULUAN}

Perjalanan wisata yang saat ini sudah menjadi kebutuhan setiap orang terutama keluarga menjadi bagian penting dari aktivitas rutin.Perjalanan selain dapat menutunkan stress dapat juga sebagai ajang kekompakan dan kedekatan. Meskipun tujuan berwisata berbeda-beda, tetapi biasanya tetap dilakukan untuk mendapatkan kesenangan. Tujuan ini dilakukan mulai dari sekedar hobi, mencari pengalaman, berwisata bersama keluarga, serta menghilangkan penat setelah bekerja sepekan. Wisatawan saat ini juga mulai banyak yang menyukai konsep wisata alam terbuka, baik itu gunung, pantai, hutan, taman, dan lainnya. Hal ini seiring dengan perkembangan teknologi media sosial yang menjadikan tempat mengabadikan perjalanannya. Alam terbuka menjadikan foto yang dibuat menjadi lebih menarik dan lebih bagus.

Di Indonesia banyak terdapat beberapa tempat wisata alam terbuka mengingat sumber daya alam yang dimiliki Indonesia sangat banyak. Salah satunya adalah agro wisata atau disebut juga wisata pertanian. Agro wisata yang cukup besar di Bogor adalah Taman Buah Mekarsari yang terletak di Cileungsi Kabupaten Bogor yang pada penelitian ini akan hanya disebutkan agro wisata di Bogor saja. Konsep yang ditawarkan mereka adalah wisata agro tanaman buah-buahan. Atraksi yang dilakukan yaitu melihat perkebunan dengan berbagai jenis tanaman buah, memetik dan memakan langsung dari pohon untuk buah musiman tertentu, jenis buah-buahan unik, serta atraksi lainnyayang merupakan hiburan tambahan seperti wahana permainan. Selain 


\section{National Conference of Creative Industry: \\ Sustainable Tourism Industry for Economic Development}

Universitas Bunda Mulia, Jakarta, 5-6 September 2018 e-ISSN No: 2622-7436

memberikan hiburan, wisata agro juga memberikan edukasi sehingga cocok juga untuk anak-anak.

Pengunjung yang datang ke agro wisata di Bogor ini termasuk cukup fluktuatif setiap tahunnya. Dalam tiga tahun terakhir selalu mengalami penurunan. Pada tahun 2016 mengalami penurunan sebanyak $21 \%$ dari tahun sebelumnya yaitu di 2015 . Pada tahun 2017 setelah dilakukan perbaikan di beberapa fasilitas mengalami penurunan sebesar 2\% dari Tahun 2016 atau sebesar 23\% dari tahun 2015. Bahkan untuk pengunjung di Tahun 2014 juga masih tinggi dibandingkan dengan jumlah pengunjung pada tahun 2016 dan 2017. Ini merupakan tantangan bagi industri untuk melakukan perubahan. Banyaknya persaingan juga mempengaruhi jumlah pengunjung tadi, hanya saja pihak penyedia jasa tidak dapat menyalahkan pihak luar tetapi harus mampu bersaing untuk menjadi yang lebih baik.

Menurunnya pengunjung atau pengguna dapat disebabkan beberapa hal, diantaranya menurunnya tingkat kepuasan sehingga tidak ingin berkunjung kembali, adanya destinasi wisata lainnya, kondisi akses yang kurang baik, dan lain sebagainya. Tetapi yang terpenting dari semua ini adalah bagaimana menjaga agar pengunjung tetap puas dengan apa yang dinikmatinya. Karena dengan kepuasan ini perilaku pengunjung dapat mempengaruhi kunjungan wisata selanjutnya seperti minat berkunjung kembali, merekomendasikan kepada orang lain, berbicara positif mengenai tempat wisata tadi, dan lain sebagainya. Word of mouth communication ini adalah sebagai dampak dari adanya kepuasan pelanggan atas pengalamannya sendiri (Tanet al., 2010).

Berdasarkan latar belakang di atas, maka perumusan masalah penelitian ini adalah bagaimana Kepuasan Pengunjung pada Destinasi Agro Wisata di Bogor?. Tujuan penelitian ini adalah untuk mengetahui Kepuasan Pengunjung pada Destinasi Agro Wisata di Bogor.Pada dasarnyapenelitian ini adalah untuk melihat kepuasan pengunjung untuk terus dilakukan inovasi agar semakin memberi kepuasan bagi para pengunjungnya.

\section{TINJAUAN PUSTAKA}

Kepuasan Pengunjung dalam hal ini kepuasan wisatawan merupakan ungkapan perasaan seseorang yang muncul setelah mendapatkan suatu produk atau jasa dan dibandingkan dengan apa yang diharapkannya. Apabila produk atau jasa yang dirasakan tadi tidak memenuhi ekspektasi wisatawan, maka pelanggan tersebut akan kecewa atau tidak puas. Begitu pula sebaliknya, apabila produk atau jasa yang dirasakan tadi memenuhi atau bahkan melebihi ekspektasi wisatawan, maka wisatawan tadi akan senang atau puas (Kotler\& Keller, 2009).

Ekspektasi atau disebut juga harapan adalah sebuah standar kualitas yang merupakan persepsi konsumen yang kemudian akan dibandingkan dengan kualitas produk atau jasa yang dirasakan konsumen sesungguhnya (Sangadji dan Sopiah, 2013). Ekspektasi merupakan keinginan atau harapan dari apa yang dirasakan wisatawan terhadap produk atau jasa yang seharusnya diterima dibandingkan dengan barang yang ditawarkan untuk diterima. Ekspektasi dan pengalaman tersebut tergantung dari persepsi masing-masing individu, pengalaman yang didapatkan sebelumnya, motivasi, informasi, manfaat yang didapatkan, serta niat berperilaku.

Kepuasan secara umum merupakan perbandingan antara ekspektasi dan pengalaman Pelanggan. Pelanggan yang merasa puas terhadap produk atau jasa yang dibeli dan 


\section{National Conference of Creative Industry: \\ Sustainable Tourism Industry for Economic Development}

Universitas Bunda Mulia, Jakarta, 5-6 September 2018

e-ISSN No: 2622-7436

digunakannya akan kembali menggunakan produk atau jasa tadi (Zeithaml dan Bitner, 2005). Dalam kaitannya dengan pariwisata, kepuasan adalah suatu keadaan emosi dan pikiran sesudah wisatawan mendapatkan pengalaman berwisata (Baker dan Crompton, 2000).

Berdasarkan faktor tersebut di atas, maka yang menjadi indikator penilaian kepuasan wisatawan adalah Kulaitas Produk, Kualitas Pelayanan, Faktor Emosional, Faktor Harga, Faktor Biaya.

Terdapat 5 faktor utama yang perlu diperhatikan terkait dengan kepuasan konsumen dalam hal ini wisatawan (Lupiyoadi, 2001). Hal tersebut antara lain adalah:

1. Kualitas Produk

Pada faktor ini, bagi seorang wisatawan akanmengatakan puas apabila hasil evaluasi mereka menunjukkan bahwa destinasi yang mereka kunjungi berkualitas baik. Sebuah destinasi yang bisa dikatakan sebuah produk dapat dikatakan berkualitas baik bagi seseorang adalah jika produk destinasi wisata tersebut dapat memenuhi kebutuhan wisatawan. Kualitas produk destinasi wisata terdiri atas dua macam yaitu eksternal dan internal. Contoh kualitas produk destinasi wisata eksternal adalah citra merek (brand image) sedangkan dari kualitas produk destinasi wisata internal adalah mutu dari produk tersebut.

2. Kualitas Pelayanan

Pada faktor ini, bagi seorang wisatawan akan mengatakan dan merasakan puas apabila mendapatkan suatu pelayanan yang baik yaitu sesuai dengan harapan mereka. Sebuah destinasi wisata memberikan pelayanan yang baik dari stafnya sehingga wisatawan merasa nyaman.

3. Faktor Emosional

Faktor emosional adalah suatu keadaan dimana konsumen akan mengatakan dan merasa puas ketika orang memberikan pujian terhadap dirinya karena telah berkunjung ke destinasi wisata yang kekinian, karena dianggap lebih update, sehingga mendapatkan prestige karena telah berkunjung ke destinasi tersebut. Destinasi yang mahal juga menjadi faktor emosional seseorang karena menjadi perhatian bagi orang-orang. Destinasi yang diinginkan orang-orang untuk didatangi juga bisa menjadi kebanggaan tersendiri. Misalnya Wisata Raja Ampat yang indah banyak dimintai orang banyak untuk dikunjungi dan ketika seseorang dapat mengunjungi Raja Ampat tersebut maka dirinya akan sangat bangga.

4. Faktor Harga

Faktor Harga merupakan harga yang dikeluarkan wisatawan sesuai dengan apa yang didapatkan atau bahkan memberikan nilai yang lebih tinggi. Terkadang wisatawan juga memilih destinasi wisata yang memberikan harga yang lebih rendah tetapi memiliki kualitas yang sama dengan yang lain yang lebih mahal.

5. Faktor Biaya

Faktor biaya yang dimaksud adalah biaya yang dikeluarkan selain harga tiket dari destinasi wisata. Dalam hal ini wisatawan tidak perlu mengeluarkan biaya tambahan ketika sudah berada di dalam tempat wisata atau tidak perlu membuang waktu untuk mengunjungi destinasi wisata yang mengakibatkan kepuasan terhadap destinasi wisata tersebut.

Berdasarkan faktor tersebut di atas, maka yang menjadi indikator penilaian kepuasan wisatawan adalah Kulaitas Produk, Kualitas Pelayanan, Faktor Emosional, Faktor Harga, Faktor Biaya. 


\section{National Conference of Creative Industry: \\ Sustainable Tourism Industry for Economic Development}

Universitas Bunda Mulia, Jakarta, 5-6 September 2018 e-ISSN No: 2622-7436

Agro Wisata atau dalam Bahasa Inggris Agro-Tourism adalah salah satu bidang usaha pertanian yang didasarkan pada konsep uniqueness yaitu berbeda dari wisata lainnya. Bukan usaha jasa pertanian biasa, Agrowisata adalah usaha bidang pertanian yang menawarkan konsep wisata dengan menjual keindahan alam pertanian serta pengetahuan bidang alam dan pertanian. Selain itu, agrowisata juga dapat berperan sebagai media promosi produk pertanian, sebagai media pendidikan, dan menjadi peluang pengembangan diversifikasi produk agribisnis (Deptan, 2008).

\section{METODOLOGI PENELITIAN}

Penelitian ini merupakan penelitian kuantitatif deskriptif yang menampilkan sebuah gambaran dari objek dan variabel yang diteliti (Sumarwan et al., 2011). Penyebaran kuesioner adalah teknik pengambilan data yang dilakukan dengan pilihan kuesioner menggunakan skala likert $1-5$. Kuesioner tersebut dibagikan ke 100 responden denganpopulasi pengunjung dalam setahun yang didapatkan dari rumus slovin.Teknik Convenience samplingdipercaya dalam pengambilan kuesioner dimana hal ini merupakan sebuah metode yang dapat memberikan kenyamanan serta kemudahan peneliti dalam memilih responden (Sekaran, 2010). Analisis data menggunakan uji statistik parametrik dengan menghitung rata-rata dan standar deviasi (Hair et al., 1995).

Variabel yang digunakan terdiri dari satu variabel yaitu Kepuasan Wisatawanyang diukur dengan menggunakan lima butir pernyataansebagai berikut: (1) Saya merasapuas telah mengunjungi destinasi agrowisata(2) Saya merasa puas mendapatkan pelayanan dari destinasi agrowisata yang sesuai dengan harapan saya (3) Saya merasa bangga telah berkunjung ke destinasi agrowisata (4) Saya merasa puas dengan harga yang ditawarkan destinasi agrowisata tetapi sama kualitasnya (5) Saya puas dengan tidak banyaknya biaya yang dikeluarkan selain harga tiket karena tidak menguras kantong.

\section{HASIL DAN PEMBAHASAN}

Pada hasil penelitian ini, data terdiri dari profil responden dan data Kepuasan Wisatawan. Profil responden yaitu jenis kelamin, usia, pekerjaan, penghasilan/uang saku, jumlah kunjungan, sumber informasi, tujuan berkunjung.Data lainnya adalah hasil dari penggambaran Kepuasan Wisatawan. Sehingga terlihat bagaimana kepuasan wisatawan setelah mengunjungi destinasi agrowisata pada penelitian ini.

Adapun profil responden pada penelitian ini terdapat pada tabel di bawah ini yaitu sebagai berikut:

Tabel 1. Profil Responden pengguna Travel Mobile Application

\begin{tabular}{cll}
\hline No & \multicolumn{1}{c}{ Pertanyaan } & \multicolumn{1}{c}{ Hasil } \\
\hline 1 & Jenis Kelamin & Laki-laki: 48\%; Perempuan: 52\% \\
2 & Usia & 16-20 Tahun: 26\%; 21-25 tahun: 39\%; 26-30 \\
& & tahun: 22\%; 31-35 tahun: 11\%; >35 tahun: 2\%. \\
3 & Pekerjaan & Mahasiswa/Pelajar: 36\%; Wiraswasta: 16\%; \\
& & PNS: 8\%; Karyawan Swasta: 34\%; lainnya: 6\%. \\
4 & Pendapatan/uang saku & Rp. 500.000 - Rp. 1.000.000: 26\%; Rp. \\
& & $1.000 .000-$ Rp. 2.500.000: 15\%; Rp. 2.600.000 \\
& & - Rp. 5.000.000: 44\%; >Rp. 5.000.000: $15 \%$. \\
\hline
\end{tabular}




\begin{tabular}{cll}
\hline 5 & Jumlah Kunjungan & 1 kali: $24 \% ; 2-3$ kali: $61 \% ; 4-5$ kali: $7 \% ;>6$ \\
& & kali: $8 \%$. \\
6 & Sumber Informasi & Sosial Media: 27\%; Mulut ke Mulut: 62\%; \\
& & Website: $9 \%$; Lainnya: $2 \%$. \\
7 & Tujuan Berkunjung & Belajar: 6\%; Piknik: 33\%; Bermain: $42 \% ;$ \\
& & Memetik buah: 13\%; Lainnya: 6\%. \\
\hline
\end{tabular}

Pada tabel di atas, memperlihatkan bahwa responden dengan jenis kelamin perempuan lebih banyak yaitu sebanyak 52\%. Usia responden dengan presentase terbesar adalah usia antara 21-25 tahun yaitu 39\%. Presentase terbesar dari pekerjaan responden adalah karyawan swasta yaitu sebanyak34\%. Presentase terbesar dari pendapatan/uang sakuresponden adalah 34\% yaitu berpenghasilan Rp. 2.600 .000 - Rp. 5.000.000. Responden yang melakukan jumlah kunjungan sebanyak 2-3 kali adalah yang terbanyak yaitu $61 \%$. Sumber informasi terbanyak adalah yang didapat dari mulut ke mulut yaitu sebesar $62 \%$. Sedangkan untuk tujuan berkunjung yang terbanyak adalah untuk bermain yaitu sebesar $42 \%$.

Hasil penelitian selanjutnya adalah data statistikdeskriptif yang dapat memberikangambaranatau mendeskripsikan data atas kepuasan wisatawan pada penelitian iniyang dapat dilihat darinilai meandanstandard deviation. Nilai meanyaitu nilai rata-rata darijawaban seluruh respondenterhadap variabel yang diteliti pada penelitian ini.Nilai standard deviationyaitu nilai simpanganbakuyang menunjukanvariasidarijawabanresponden. Berikut adalah hasil dari kuisioner yang dibagikan kepada responden.

Tabel 2. Statistik Deskriptif Kepuasan Pelanggan

\begin{tabular}{|c|c|c|}
\hline Item Pernyataan & Mean & $\begin{array}{c}\text { Std. } \\
\text { Deviation } \\
\end{array}$ \\
\hline $\begin{array}{l}\text { 1. Saya merasa puas telah mengunjungi } \\
\text { destinasi agrowisata. }\end{array}$ & 3,80 & 0,557 \\
\hline $\begin{array}{l}\text { 2. Saya merasa puas mendapatkan } \\
\text { pelayanan dari destinasi agrowisata } \\
\text { yang sesuai dengan harapan saya. }\end{array}$ & 3,74 & 0,588 \\
\hline $\begin{array}{l}\text { 3. Saya merasa bangga telah berkunjung } \\
\text { ke destinasi agrowisata. }\end{array}$ & 3,74 & 0,505 \\
\hline $\begin{array}{l}\text { 4. Saya merasa puas dengan harga yang } \\
\text { ditawarkan destinasi agrowisata tetapi } \\
\text { sama kualitasnya. }\end{array}$ & 3,66 & 0,501 \\
\hline $\begin{array}{l}\text { 5. Saya puas dengan tidak banyaknya } \\
\text { biaya yang dikeluarkan selain harga } \\
\text { tiket karena tidak menguras kantong. }\end{array}$ & 3,59 & 0,502 \\
\hline Rata-rata & 3,53 & 0,536 \\
\hline
\end{tabular}

Berdasarkan Tabel 2,menunjukkan bahwa yang membentuk konstrukKepuasan Wisatawanmemiliki nilai mean (rata-rata)yaitu sebesar 3,53; dimana nilai masingmasing mean dari item pernyataan adalah sebesar 3,$80 ; 3,74 ; 3,74 ; 3,66 ; 3,59$. Hal ini berarti rata-rata wisatawan yang berkunjung ke destinasi agriwosata di Bogor merasa puas dengan tempat wisata tersebut, mendapatkan pelayanan sesuai dengan ekspektasi, merasa bangga, puas dengan harga dan biaya yang dikeluarkan.Untuk nilai standar 


\section{National Conference of Creative Industry: \\ Sustainable Tourism Industry for Economic Development}

Universitas Bunda Mulia, Jakarta, 5-6 September 2018

e-ISSN No: 2622-7436

deviasi secara keseluruhan untukKepuasan Wisatawansebesar 0,536. Hal ini menunjukkan data yang dikumpulkan terpusat atau mengumpul, yang berarti data tersebut baik.

\section{KESIMPULAN}

Hasil yang didapatkan bahwa sebagian besar responden yang merupakan wisatawan menyatakan bahwa mereka secara umum puas. Wisatawan yang berkunjung ke destinasi agriwosata di Bogor merasa puas dengan tempat wisata tersebut, mendapatkan pelayanan sesuai dengan ekspektasi, merasa bangga, puas dengan harga dan biaya yang dikeluarkan. Hal ini tentunya menjadi masukan untuk penyedia jasa untuk menjadikan wisatawan yang berkunjung menyatakan sangat puas atau sangat puas sekali dari 5 faktor yang terdapat dalam item pernyataan.

Saran bagi penyedia destinasiAgrowisata di Bogor initentunya agar terus melakukan peningkatan kualitas dari produk destinasi wisata agrowisata sehingga semakin membuat wisatawan puas. Untuk saran bagi poin yang terkecil pada item pernyataan kepuasan pelanggan yaitu pada faktor biaya dimana wisatawan merasa mereka mengeluarkan biaya lagi pada saat akan menggunakan beberapa wahana di dalam destinasi agrowisata ini sehingga penilaian responden menjadi rendah. Untuk itu perlu adanya paket-paket untuk mempermudah wisatawan melakukan pilihan wahana apa saja yang akan dipilihnya karena jika harga termasuk semua permainan juga wisatawan akan merasa rugi karena tidak semua wahana dikunjungi. Selain itu, dengan memperbanyak wahana yang bebas dari biaya tambahan juga salah satu upaya untuk meningkatkan kepuasan dari faktor biaya.

\section{DAFTAR PUSTAKA}

Baker, D. A., \& Crompton, J. L. 2000. Quality, satisfaction, and behaviour intentions. Annals of Tourism Research.

Departemen Pertanian. 2008. Agrowisata Meningkatkan Pendapatan Petani. Direktori Profil Agrowisata.

Hair J.F; Rolph E.A.; Ronald L.T; and William, C. Black.1995.Multivariate Data Analysis, United Stated of America: Pearson Prentice Hall International Editions.

Hardjosoedarmo, Soewarso. 1997. Dasar-dasar Total Quality Management. Yogyakarta: Penerbit Andi.

Irawan, Handi D. 2009.10 Prinsip Kepuasan Pelanggan. Edisi Kedua 2002. Jakarta: Elex Media Komputindo.

Kotler, Philip dan Keller, Kevin L. 2009. Manajemen Pemasaran, Edisi Ketiga Belas, terjemahan dalam Bahasa Indonesia. Jakarta: Penerbit Erlangga.

Lovelock, C. dan Wirtz, J. 2011. Services Marketing: People, Technology, Strategy. Pearson Education, Inc, New Jersey.

Lupiyoadi, Rambat. 2001. Manajemen Pemasaran Jasa: Teori dan Praktek. Jakarta: Salemba Empat.

Sangaji, Etta Mamang dan Sopiah. 2013. Perilaku Konsumen. Yogyakarta: Penerbit Andi. 
Sekaran, Uma. 2010. Research Methods for Business, United States of America: John Willey and Sons, Inc.

Sumarwan, Ujang; Jauzi, Ahmad; Mulyana, Asep; Karno, Bagio N.; Mawardi, Ponti K.; dan Nugroho, Bayu. 2011. Riset Pemasaran dan Konsumen. IPB Press, Bogor.

Tan, W. J., Kwek, C. L., and Li, L. 2013. "The Antecedents of Effectiveness Interactive Advertising in the Social Media," International Business Research, Vol. 6, No. 3.

Yuniarti, Vinna Sri. 2015. Perilaku Konsumen: Teori dan Praktik. Bandung: Pustaka Setia Bandung.

Zeithaml, Valerie A. dan Bitner, Mary Jo. 2005. Customer Contribution and Roles in Service Delivery. North Carolina: University of North Carolina. 